\section{Application of Atomic Absorption Spectroscopy in the Determination of the Elemental Composition of Chanca piedra (Stone Breaker Leaf) Growing in Iwo, South West Nigeria}

\author{
Oladipo Olukunle Adejumo ${ }^{{ }^{*}}$, Olusegun Isaac Alarapon ${ }^{1}$, Olufunmilayo Ebunoluwa Adejumo ${ }^{2}$ and Margaret Kofoworola Akinloye ${ }^{3}$ \\ ${ }^{1}$ Department of Physics and Solar Energy, Bowen University, Iwo, Nigeria \\ ${ }^{2}$ Department of Pharmaceutical and Medicinal Chemistry, Olabisi Onabanjo University, Sagamu, Nigeria \\ ${ }^{3}$ Department of Pure and Applied Physics, Ladoke Akintola University of Technology, Ogbomoso, Nigeria
}

*Corresponding author: Oladipo Olukunle Adejumo, Department of Physics and Solar Energy, Bowen University, Iwo, Nigeria, E-mail: oladipoadejumo@yahoo.com Received date: February 21, 2018; Accepted date: March 6, 2018; Published date: March 12, 2018

Copyright: ( 2018 Adejumo OO, et al. This is an open-access article distributed under the terms of the Creative Commons Attribution License, which permits unrestricted use, distribution, and reproduction in any medium, provided the original author and source are credited.

\begin{abstract}
The elemental composition of Chanca piedra (stone breaker leaf) alternatively called Phyllantus amarus (Euphorbiaceae) was determined using atomic absorption spectroscopy, AAS. Chanca piedra a tropical medicinal plant, is reportedly useful in blocking kidney stone formation and has anti-hepatitis B activity. The acid digested samples were subjected to AAS analysis. The atomic absorption spectrophotometer (PG-990) is a fully automated instrument used in the flame configuration option, controlled by a personal computer, with Microsoft windows as the operating system. Results showed that manganese (Mn) $(228.9 \pm 3.3 \mathrm{mg} / \mathrm{kg})$, zinc ( $\mathrm{Zn})(41.7 \pm 0.9 \mathrm{mg} / \mathrm{kg})$, iron (Fe) $(459.3 \pm 3.3 \mathrm{mg} / \mathrm{kg})$, calcium (Ca) $(521.9 \pm 1.8 \mathrm{mg} / \mathrm{kg})$ and magnesium $(\mathrm{Mg})(397.4 \pm 1.3 \mathrm{mg} / \mathrm{kg})$ were present in the plant. These high concentrations of calcium, iron and magnesium in this plant should be useful for electrolyte balance, enhancement of growth, bone and teeth formation, and activation of enzyme reactions. It should also have implications for drug development in this part of the world for the treatment of some kidney and other related medical problems. The result equally shows the suitability of Chanca piedra leaves for consumption and confirms its folkloric applications in traditional medications.
\end{abstract}

Keywords: Atomic absorption spectrometry; Elemental composition; Chanca piedra; Phyllantus amarus, Drug development

\section{Introduction}

Phyllantus, is a large genus and widely distributed in tropical and subtropical areas of Africa, America, Asia and Oceania [1]. The species, Phyllantus amarus belonging to the family Euphorbiaceae is a widespread herb in southern Nigeria where it is often regarded as a weed [2]. In Nigeria, traditional medicinal practitioners have used this plant in various forms for treatment of diseases of wide physiological or biochemical causes such as stomach disorders, skin diseases, cold, infertility, snake bites and vomiting [3]. Lutterodt, [4] showed that a poultice of the leaves mixed with salt cured itch and other skin infections. For generations of Amazonian indigenous peoples, this plant is used effectively in eliminating gallstones and kidney stones, and its Spanish name, Chanca piedra, which means "stone breaker" or "shatter stone" is a consequence of this effective usage. Other conditions, for which this plant is employed for, include gonorrhea symptoms, colic, diabetes, malaria, dysentery, fever, flu, tumours, jaundice, vaginitis, and dyspepsia. In other regions of the world, like the Bahamas/Caribbean, Brazil, Haiti, India, Malaya, Peru, United States and elsewhere, this plant has found ethnobotanical usage as herbal remedy [5]. Here in South-west Nigeria, this plant is known locally as eyin olobe among the indigenous Yoruba people, where there exists an unpublished claim that a patient diagnosed with gall stones, after taking unregulated doses of extractions from this plant's leaves was relieved of the ailment [6]. The plant is known among the Hausas of Northern Nigeria as Gerontsunsaye [7]. Since the mid-1960s, Chanca piedra has been the subject of much phytochemical research to determine the active constituents and their pharmacological activities. It is a rich source of phytochemicals, including many which have been found only in the Phyllanthus genus. Chanca piedra is a perfect example of a highly beneficial medicinal plant, which deserves of much more research-but one which is fraught with the typical problems of working with a complicated, phytochemically-rich plant [5]. Factors that are considered by health care providers when recommending herbs include the species, variety of the plant, plant habitat and how it was stored and processed.

Consequent of the claims of the medicinal benefits of Chanca piedra leaf, this study sets out to determine the elemental composition of the plant with Iwo, South-west Nigeria as habitat using atomic absorption spectroscopy (AAS). It is expected that the qualitative (elemental composition) and quantitative (elemental concentrations) results of this study should contribute to drug development in this part of the world, to assist in the development of appropriate drugs for the cure of kidney and gall bladder stones as well as other related ailments. Also, a scientific platform from which objective deductions can be made on the therapeutic properties and other medicinal benefits of this plant will develop.

\section{Materials and Methods}

\section{Plant collection and authentication}

Chanca piedra plant grows $50-70 \mathrm{~cm}$ tall and bears ascending herbaceous branches. The bark is smooth and light green. The fruits are tiny, smooth capsules containing seeds. The plant was identified and collected in March 2017 around the Bowen University Campus in 
Citation: Adejumo OO, Alarapon IO, Adejumo OE, Akinloye MK (2018) Application of Atomic Absorption Spectroscopy in the Determination of the Elemental Composition of Chanca piedra (Stone Breaker Leaf) Growing in Iwo, South West Nigeria. J Exp Food Chem 4: 136. doi: $10.4172 / 2472-0542.1000136$

Page 2 of 3

Iwo, Osun State, Nigeria. It was authenticated at the herbarium of the Forestry Research Institute of Nigeria (FRIN), Ibadan where a voucher specimen with number FHI 110869 was deposited. Collected sample was then taken to Chemistry Laboratory of the University for Sample preparation. The digested sample was analysed with the PG 990 Atomic Absorption Spectrophotometer available at the Central Science Research Laboratory of the University.

\section{Sample preparation}

The plant sample was air-dried in the laboratory and digested. One (1) $g$ of plant sample was measured using analytical weighing balance. Concentrated $\mathrm{HNO}_{3}(5 \mathrm{ml})$ was added to the weighed sample in a Teflon beaker and heated on a hot plate for about $10 \mathrm{~min}$ after which 1 $\mathrm{ml}$ of perchloric acid was added and then heated for about 30-45 min. The digested sample was allowed to cool to room temperature and filtered. The filtrate was then transferred into a $25 \mathrm{ml}$ volumetric flask and made up to mark with distilled water. Two other replicate samples were prepared to achieve triplicate measurements.

\section{Theory and instrumentation}

The Atomic Absorption Spectroscopy technique determines the concentrations of chemical elements present in a given sample by measuring the absorbed radiation of the chemical element of interest by reading the spectra produced when the sample is excited. The three main techniques for AAS; flame, graphite and hydride all have their own advantages and disadvantages depending on analytical problems. The five essential components of an atomic absorption spectrophotometer, namely, the light source, the burner assembly, optics, detector and signal processing are designed such that each component produces minimum disruption to the overall system and many design features are installed to keep the signal-to-noise ratio as low as possible. In this work, the line source PG-990 Atomic Absorption Spectrophotometer, LS AAS located at the Central Science Research Laboratory of the Bowen University, Iwo was used in the flame configuration mode for the elemental analysis. It is a fully automated instrument for flame and/or graphite furnace analysis developed by PG Instruments Ltd. This instrument incorporates two background correction systems, the deuterium lamp method and the self-reversal method.

\section{Atomic absorption spectrometer analysis}

Air was allowed to mix with acetylene gas from the gas cylinder in good proportion to ignite the burner of the Spectrophotometer. Immediately after ignition, the spectrophotometer was calibrated using blank (distilled water) and standard solution (as supplied with the spectrophotometer). The aerosol of the sample was then aspirated through the nebulizer into the flame for analysis. Analysis was done for each element of interest at their specific wavelength using the hollow cathode lamp of the element under investigation. Finally, the result is displayed on the computer read-out.

\section{Results}

The mean concentration of the elements $\mathrm{Mn}, \mathrm{Zn}, \mathrm{Fe}, \mathrm{Ca}$ and $\mathrm{Mg}$ analysed for the stone breaker solution is presented in Table 1 below. The data have been presented at 95\% ( $\pm 2 \mathrm{~S})$ confidence level for triplicate measurements in each of the cases. Table 2 shows the daily dietary allowance for the elements analysed as recommended by
National Research Council, USA, (Recommended Dietary Allowances, $10^{\text {th }}$ Edition, 1989).

\begin{tabular}{|l|l|}
\hline Elements & Concentration, $\mathbf{~ m g} / \mathbf{k g}$ \\
\hline $\mathrm{Mn}$ & $228.8 \pm 3.3$ \\
\hline $\mathrm{Zn}$ & $41.7 \pm 0.9$ \\
\hline $\mathrm{Fe}$ & $459.3 \pm 3.3$ \\
\hline $\mathrm{Ca}$ & $521.9 \pm 1.8$ \\
\hline $\mathrm{Mg}$ & $397.4 \pm 1.3$ \\
\hline
\end{tabular}

Table 1: Concentration of elements in Chanca piedra.

\begin{tabular}{|c|c|}
\hline \multirow[t]{2}{*}{ Elements } & $\begin{array}{l}\text { Recommended Dietary Allowances per day } \\
\text { (mg) }\end{array}$ \\
\hline & Male \\
\hline $\mathrm{Mn}$ & $2-5$ \\
\hline $\mathrm{Zn}$ & 15 \\
\hline $\mathrm{Fe}$ & 10 \\
\hline $\mathrm{Ca}$ & 800 \\
\hline $\mathrm{Mg}$ & 320 \\
\hline
\end{tabular}

Table 2: Recommended dietary allowances per day of elements for humans.

\section{Discussions and Conclusion}

The determination of the elemental composition of Chanca piedra (stone breaker leaf) using AAS technique showed that calcium had the highest concentration of $521.9 \pm 1.8 \mathrm{mg} / \mathrm{kg}$, followed by iron with $459.3 \pm 3.3 \mathrm{mg} / \mathrm{kg}$, then, magnesium with $397.4 \pm 1.3 \mathrm{mg} / \mathrm{kg}$, and manganese followed with $228.9 \pm 3.3 \mathrm{mg} / \mathrm{kg}$ and lastly zinc with $41.7 \pm$ $0.9 \mathrm{mg} / \mathrm{kg}$. These high concentrations of calcium, iron and magnesium in this plant should be useful for electrolyte balance, enhancement of growth, bone and teeth formation; activation of enzyme reactions and for drug development in the pharmaceutical industry for the treatment of some kidney and other related medical problems in this part of the world. The concentrations of $\mathrm{Ca}, \mathrm{Fe}$ and $\mathrm{Mg}$ could be attributed to the environment where the plant was collected and the activities taking place there. The concentrations of $\mathrm{Ca}$ and $\mathrm{Mg}$ might enhance the medicinal activity of the leaves of Chanca piedra since both are minerals beneficial to the human body. Magnesium is essential for life and is a co-factor in numerous enzymes involved in phosphate transfer, muscle contractility and neuronal transmission. Deficiency of $\mathrm{Mg}$ can result in tetany and lead to calcium deficiency [8]. Iron is a constituent of haemoglobin, myoglobin, and a number of enzymes and, therefore, is an essential nutrient for humans [9]. An association between haemoglobin concentration and work capacity is the most clearly identified functional consequence of iron deficiency [10]. Iron deficiency also has been associated with decreased immune function as measured by changes in several components of the immune system during iron deficiency. In children, iron deficiency has been associated with apathy, short attention span, irritability, and reduced ability to learn [11]. Manganese is a major component of the mitochondrial antioxidant enzyme manganese superoxide dismutase. Signs of 
Citation: Adejumo OO, Alarapon IO, Adejumo OE, Akinloye MK (2018) Application of Atomic Absorption Spectroscopy in the Determination of the Elemental Composition of Chanca piedra (Stone Breaker Leaf) Growing in Iwo, South West Nigeria. J Exp Food Chem 4: 136. doi: $10.4172 / 2472-0542.1000136$

Page 3 of 3

deficiency include poor reproductive performance, growth retardation, congenital malformations in the offspring, abnormal formation of bone and cartilage, and impaired glucose tolerance [12]. Zinc, a constituent of enzymes involved in most major metabolic pathways, is an essential element for plants, animals, and humans [13]. The signs and symptoms of dietary zinc deficiency in humans include loss of appetite, growth retardation, skin changes, and immunological abnormalities. Pronounced zinc deficiency in men resulting in hypogonadism and dwarfism has been found in the Middle East [14]. In human patients with low plasma zinc levels, accelerated rates of wound healing have been observed as a result of increased zinc intake, suggesting that the zinc requirement of these subjects was not fully met by their diets [15]. Adejumo and Ajayi [16], reported the mineral element composition in Phyllanthus amarus as folows: calcium $(2700.00 \pm 400.00 \mathrm{mg} / 100 \mathrm{~g})$, iron $(50.27 \pm 1.47 \mathrm{mg} / 100 \mathrm{~g})$, magnesium $(1766.67 \pm 66.70 \mathrm{mg} / 100 \mathrm{~g})$, manganese $(38.18 \pm 2.07 \mathrm{mg} / 100 \mathrm{~g})$ and zinc $(110.33 \pm 2.01 \mathrm{mg} / 100 \mathrm{~g})$. Comparing these results with ours, we observe that high concentrations of calcium and magnesium were also obtained in our study. However, the variations in the concentration values for the other elements may be due to the site and time of sample collection, environmental influences, soil types and composition, as well as activities taking place there [17]. In the 2009 study by Adejumo and Ajayi, the Phyllanthus amarus samples were collected within the locality of Olabisi Onabanjo University Teaching Hospital, Sagamu, Nigeria in August 2004, while current sample was collected from Bowen University campus, Iwo.

Comparing the results obtained in Table 1 with the Recommended Dietary Allowance, RDA values per day, shown in Table 2, it is observed that consumption of a few grams of this leaf is well within tolerable limits of the RDA values. This result therefore shows the suitability of Chanca piedra leaves for consumption and confirms its folkloric applications in traditional medications aside having implications for drug development.

\section{Acknowledgements}

This research did not receive any specific grant from funding agencies in the public, commercial or not-for-profit sectors.

\section{References}

1. Mao X, Wu LF, Guo HL, Chen WJ, Cui YP, et al. (2016) The Genus Phyllanthus: An Ethnopharmacological, Phytochemical, and
Pharmacological Review. Evid Based Complement Alternat Med 2016: 7584952.

2. Odetola AA, Akojeun SM (2000) Anti-diarrhoeal and gastro-intestinal potentials of the aqueous extract of Phyllanthus amarus (Euphorbiaceae). Afr J Med Sci 29: 119-122.

3. Iwu MM (1993) Modalities of Drug Administration In: Handbook of African Medicinal Plants. CRC Press Inc. Florida, 309-330.

4. Lutterodt GD (1989) Inhibition of gastrointestinal release of acetylcholine by quercetin as a possible mode of action of Psidium guajava leaf extract in the treatment of acute diarrhoea disease. J. Ethnopharmacology 25: 235-247.

5. Taylor Leslie (2003) Technical Data Report for Chanca Piedra "Stone Breaker" (Phyllanthus niruri). Sage Press Inc, PO Box 80064, Austin, TX.

6. Adisa A (2015) Private communication.

7. Gafar MK, Itodo AU, Senchi DS (2012) Nutritive and anti-nutritive composition of chanca piedra (stone breaker). Food and Pubic Health 2: 21-27.

8. Travers CA (2004) Iodine status in pregnant women and their newborns. Are our babies at risk of iodine deficiency? Med J Austr 42: 152-156.

9. Bothwell TH, Charlton RW, Cook JD, Finch CA (1979) Iron metabolism in man. Blackwell, Oxford.

10. Viteri FE, Torun B (1974) Anaemia and physical work capacity. Clin Haematol 3: 609-626.

11. Lozoff B, Brittenham GM (1986) Behavioral aspects of iron deficiency. Prog Haematol 14: 23-53.

12. Hurley LS, Keen CL (1987) Manganese. Pp. 185-223 in W. Mertz, ed. Trace Elements in Human and Animal Nutrition, Vol. 1. Academic Press, Orlando, Fla.

13. Hambidge KM, Casey CE, Krebs NF (1986) Zinc. pp. 1-137 in W. Mertz, ed. Trace Elements in Human and Animal Nutrition, Vol. 2. 5th ed. Academic Press, Orlando, Fla.

14. Prasad AS (1982) Clinical and biochemical spectrum of zinc deficiency in human subjects. Pp. 3-62 in A.S. Prasad, ed. Clinical, Biochemical, and Nutritional Aspects of Trace Elements. Current Topics in Nutrition and Disease, Mineral and bone homeostasis Vol. 6. Alan R. Liss, New York.

15. Pories WJ, Mansour EG, Plecha FR, Flynn A, Strain WH (1976) Metabolic factors affecting zinc metabolism in the surgical patient. Pp. 115-141 in A.S. Prasad, ed. Trace Elements in Health and Disease. Vol. 1, Zinc and Copper. Academic Press, New York.

16. Adejumo OE, Ajayi IA (2009) Phyto-chemical and elemental analysis of some Nigerian herbal plants with known diarrhoea properties. International Jour Chem 19: 25-30.

17. Sovljanski R, Obradovie S, Kisgeci J, Lazie S, Macko V (1989) The heavy metal content and quality of hops canoes treated by pesticides during the vegetation. Acta Hortic 249: 81-88. 